\title{
Analysis of thermal dependence on the germination of braquiarão seeds using the thermal time model
}

\author{
E. A. Nakao ${ }^{a *}$ and V. J. M. Cardoso ${ }^{a}$ \\ a'Grupo de Ecofisiologia de Sementes, Laboratório de Fisiologia Vegetal, Programa de Pós-graduação em Ciências \\ Biológicas, Departamento de Botânica, Universidade Estadual Paulista "Júlio de Mesquita Filho" - UNESP, \\ Avenida 24A, 1515, CEP 13506-9000, Rio Claro, SP, Brazil \\ *e-mail: nakaojp@hotmail.com
}

Received: August 18, 2014 - Accepted: October 25, 2014 - Distributed: February 29, 2016

(With 4 figures)

\begin{abstract}
This paper analyzed the thermal dependence on the germination of Urochloa brizantha (Stapf) Webster seeds under constant and fluctuating temperatures through the thermal time model. Germination tests were carried out at constant temperatures ranging from $8{ }^{\circ} \mathrm{C}$ to $41.5^{\circ} \mathrm{C}$ in order to determine the model parameters: base (Tb), optimal (To) and maximum temperature $(\mathrm{Tc})$ for germination; and the thermal time $\left(\theta_{\mathrm{T}}\right)$ required for individual seeds to germinate. Braquiarão seeds germinate within a temperature interval from $8{ }^{\circ} \mathrm{C}$ to $41.5^{\circ} \mathrm{C}$, with an optimum range for germination estimated at $31.5^{\circ} \leq \mathrm{T} \leq 34.5^{\circ} \mathrm{C}$. Actual and expected distributions of cumulative germination percentages of $U$. brizantha seeds put to germinate both under controlled and uncontrolled temperature regimes were compared, and it can be seen that the model described relatively well the germination at isothermal assays; however the model failed to predict germination at a wide range of thermal fluctuations. Possible explanations for the results are discussed.
\end{abstract}

Keywords: Urochloa brizantha, temperature, degrees-day.

\section{Análise da dependência térmica da germinação de braquiarão utilizando o modelo tempo térmico}

\begin{abstract}
Resumo
Este artigo analisou a dependência térmica da germinação de sementes de Urochloa brizantha em regimes de temperaturas constantes e variáveis, por intermédio do modelo do tempo térmico. Foram realizados testes de germinação em temperaturas constantes $8{ }^{\circ} \mathrm{C}$ a $41.5^{\circ} \mathrm{C}$, com o objetivo de se determinar os parâmetros do modelo: as temperaturas base (Tb), ótima (To) e máxima (Tc) de germinação, bem como a quantidade de "graus-dias" $\left(\theta_{\mathrm{G}}\right)$ necessária para a germinação de sementes individuais. As sementes de braquiarão germinaram no intervalo térmico de $8{ }^{\circ} \mathrm{C}$ to $41.5^{\circ} \mathrm{C}$, sendo que a faixa ótima foi de 31.5 a $34.5^{\circ} \mathrm{C}$. As distribuições acumuladas esperadas e observadas das porcentagens de germinação de sementes de $U$. brizantha postas para germinar tanto em temperaturas constantes como em regime térmico não controlado foram comparadas, podendo-se observar que o modelo descreveu relativamente bem a germinação nos ensaios isotérmicos, entre o mesmo falhou em prever a germinação em situações mais amplas de variação térmica. Possíveis explicações para esses resultados são discutidas.
\end{abstract}

Palavras-chave: Urochloa brizantha, temperatura, graus-dia.

\section{Introduction}

Seeds are a major means by which plants are dispersed, and the success with which the young seedling is established is greatly dependent on the germination process which, in turn, is determined by the physiological and biochemical features of the seed modulating its perception and response to environmental factors such as temperature (Bewley et al., 2013). The effect of temperature ( $\mathrm{T}$ ) on germination can be described in terms of cardinal temperatures: Minimum T (Tb); Optimum T (To) and; Maximum T (Tc). The minimum and maximum temperatures correspond, respectively, to

the lower and upper limits below or above which seed germination will not occur; while To is the temperature or temperature range - where germination is most rapid (Cardoso, 2011). Based on these assumptions, the concept of thermal time or degree-days is based on the hypothesys that the germination rate increases linearly with temperature and is directly proportional to the difference between $\mathrm{T}$ and $\mathrm{Tb}$, up until the To limit. This concept can be expressed by the equation (1): $\theta_{\mathrm{T}(\mathrm{G})}=(\mathrm{T}-\mathrm{Tb}) . \mathrm{t}_{\mathrm{G}}$, where $\theta_{\mathrm{T}(\mathrm{G})}$ is the "thermal time" or adjusted time (in units of "degree-days" 
or "degree-hours") for a given germination percentage $\mathrm{G}$, and $\mathrm{t}_{\mathrm{G}}$ is the chronological time for germination of a percentage of seeds (Bradford, 1995). Thus, once Tb has been identified for a species or a seed batch, and the total amount of degree-days for germination is thorough and known, the actual temperature for germination in any time could be estimated from equation (1). For temperatures above To, when the germination speed decreases with increasing $\mathrm{T}$, it is assumed that $\theta_{\mathrm{T}}$ remains the same for all seeds, in which case it is Tc that varies according to the percentage fraction $\mathrm{G}$, which may be expressed by equation (2): $\theta_{T}=\left(T_{c(G)}-T\right) \cdot t_{G}$, where $T_{c(G)}$ is the maximum temperature for germination of a $\mathrm{G}$ percentage (Bewley et al., 2013). The degree-days model allows estimating the time required for a given development - in this case, germination - to be completed based on the history of thermal variation of the period at issue (Trudgill et al., 2005). This is grounded on the assumption that any one particular step of the process requires a certain amount of degree-days $\left(\theta_{\mathrm{T}}\right)$ to be completed.

Urochloa brizantha cv. basilisk (Poaceae), henceforth referred to as braquiarão, was first brought to Brazil as forage for livestock, adapting very well to "Cerrado" regions. Species from the genus Urochloa prevail in Brazilian pastures and are estimated to cover approximately 102 million hectares (Pancera Junior, 2011). Nevertheless, this tropical species is a highly effective invader, potentially causing great damage to agriculture (Barbosa et al., 2008).

According to Begon et al. (2007), the best way to prevent the establishment of invasive species is to determine which ones have the greatest probability of establishment and subsequently focusing the control efforts on those species. Thus, studies on reproductive biology, dispersion, recruitment and autoecology become crucial. In the case of grasses, management often centers on controlling seed germination and seedling establishment. Consequently, tools that enable estimation of these parameters, such as the thermal time model are important in controlling these invasive species in the field, determining the best times for sampling and application of control methods (Bradford, 2002).

Considering that thermal time model has been employed as a tool for studying the temperature dependence on germination (Belo et al., 2014; Nori et al., 2014) and that germination models based on thermal time have been reasonably successful in predicting both weed and non-weed seedling emergence (Bewley et al., 2013), the aim of this study was to determine how the germination response of Urochloa brizantha seeds to constant and variable temperatures can be described by the thermal time model. It was hypothesized that the model assumptions germination rate increases linearly between $\mathrm{Tb}$ and $\mathrm{To}$ and decreases between To and Tc; Tb is similar for all seeds in the population; and Tc varies with seeds - are met for braquiarão diaspores.

\section{Material and Methods}

Seeds of braquiarão cv. basilisk, acquired in March 2010, were used in this study. They came from a company called "PRÓSEMENTES" from Araçatuba, São Paulo,

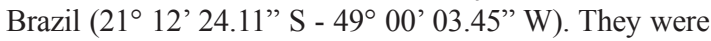
harvested in April 2009 and stored at $24^{\circ} \mathrm{C}$, and $60 \%$ relative humidity. The lot showed circa $70 \%$ maximum germination. After their acquisition, the seeds remained stored at $9 \pm 3{ }^{\circ} \mathrm{C}$ during 18 months. The seed viability, assessed monthly by germination tests performed at $25 \pm 1{ }^{\circ} \mathrm{C}$ on water- saturated filter papers, did not change throughout the experiments.

\subsection{Germination under isothermal conditions (Assay 1)}

This test aimed at estimating the degree-days model parameters, which were later used to predict germination under non-controlled conditions (Assay 2). The assay was performed in a thermo-gradient block (Cardoso, 2010) at seventeen constant temperatures ranging from $8{ }^{\circ} \mathrm{C}$ to $41.5^{\circ} \mathrm{C}$. Seeds were placed on two strips of water-saturated filter papers supported by a thermoplastic PVC base groove that was placed into a $2.5 \times 25 \mathrm{~cm}$ test tube equipped with a aluminum cap. Each tube containing 50 seeds was then horizontally positioned in the block, with four tubes per temperature. Counts were performed daily over a 60 days period (time required for ceasing germination events, at $8^{\circ} \mathrm{C}$ ), with the protrusion followed by gravitropic curvature of the primary root being adopted as germination criterion. The non-germinated seeds were subjected to a tetrazolium test (Brasil, 2009) in order to assess for viable seeds.

For a general assessment of the seed batch's germination temperature dependence and definition of the infra and supra-optimal ranges, the variables germinability ( $\mathrm{G} \%$ ), mean germination rate $(\mathrm{R})$ and synchronization of germination $(\mathrm{U})$ were calculated according to Labouriau and Agudo (1987).

An initial estimate of the model parameters ( $\mathrm{Tb}, \mathrm{Tc}$ and $\theta_{\mathrm{T}}$ ) was obtained through regression analysis of the reciprocal of the times for germination of a given seed fraction on $\mathrm{T}$ (Garcia-Huidobro et al., 1982), with Tb and Tc corresponding to the intercepts on abscissa and $1 / \theta_{\mathrm{T}}$ the slopes of the regression lines. For a more accurate estimation of the model parameters, a probit regression analysis was also used assuming that at the infra optimum interval $\theta_{\mathrm{T}}$ (referred to as $\left.\theta_{(\mathrm{G})}\right)$ is normally distributed among the seeds and $\mathrm{Tb}$ is constant, while in the supra optimal interval $\theta_{\mathrm{T}}$ is constant and $\mathrm{Tc}$ (referred to as $\mathrm{Tc}_{(\mathrm{G})}$ ) is normally distributed within the seed population. For this purpose, the cumulative daily probit transformed percentages of the combined data from a range of infra optimum temperatures were regressed on $\log \theta_{(\mathrm{G})}$ and different values of Tb were tried until the best fit (highest coefficient of determination) (Bradford, 1995). Alternatively, for supra optimum $T$ the probit transformed percentages were regressed on $\log \mathrm{Tc}_{(\mathrm{G})}$, and different $\theta$ were tested until the best fit. The models were: probit $_{(\mathrm{G})}=\left\{\log \left[(\mathrm{T}-\mathrm{Tb}) \cdot \mathrm{t}_{\mathrm{G}}\right]-\theta_{(50)}\right\} / \sigma_{\theta(\mathrm{G})}$, for infra optimum $\mathrm{T}$; and probit $_{(\mathrm{G})}=\left\{\log \left[\left(\mathrm{Tc}_{(\mathrm{G})}-\mathrm{T}\right) \cdot \mathrm{t}_{\mathrm{G}}\right]-\mathrm{Tc}_{(50)}\right\} / \sigma_{\mathrm{Tc}(\mathrm{G})}$, for supra optimum T, where: $\sigma_{\theta(\mathrm{G})}$ and $\sigma_{\mathrm{Tc}(\mathrm{G})}$ are the standard deviation of the $\theta_{\mathrm{G}}$ and $\mathrm{Tc}_{(\mathrm{G})}$ distributions, respectively; $\theta_{(50)}$ is the median thermal time; and $\mathrm{Tc}_{(50)}$ is the median ceiling temperature (Bradford, 1995). 


\subsection{Germination under fluctuating temperatures (Test 2)}

The assay was carried out in green house under variable light and temperature conditions. The seeds were placed to germinate between two sheets of water-saturated filter papers laid on a mixed substrate composed by a commercial substrate $\left(\right.$ Plantmax $\left.^{\circledR}\right)$, coarse sand, soil and vermiculite at a 2:2:1:1 ratio, put into $500 \mathrm{~mL}$ rectangular $(10 \times 15 \times 3 \mathrm{~cm})$ aluminum foil trays filled with $400 \mathrm{~mL}$ of the mix. Analysis of substrate fertility indicated $\mathrm{pH}=6.52$, organic matter $=87 \mathrm{~g} \cdot \mathrm{dm}^{-3}$, phosphorus $=260 \mathrm{mg} \cdot \mathrm{dm}^{-3}$, potassium $=39.92 \mathrm{mmolc} \cdot \mathrm{dm}^{-3}$, calcium $=174$ mmolc $\cdot \mathrm{dm}^{-3}$, magnesium $=28 \mathrm{mmolc} \cdot \mathrm{dm}^{-3}$, potential acidity $=11.70 \mathrm{CTC}=253.62$, base saturation $=95.39$, iron $=98 \mathrm{mg} \cdot \mathrm{dm}^{-3}$ manganese $=10.1 \mathrm{mg} \cdot \mathrm{dm}^{-3}$, zinc $=52.9 \mathrm{mg} \cdot \mathrm{dm}^{-3}$ and copper $=5.8 \mathrm{mg} \cdot \mathrm{dm}^{-3}$.

Five replicates (trays) with 100 seeds each were used for each sowing. The trays were kept on benches in the greenhouse under full sunlight and natural photoperiod and room temperature. Sowings were made monthly from September 2010 to August 2011 (totaling 12 sowings) and the germination (protrusion and gravitropic curvature of the primary root) was followed over 30 days period. The substrate was kept wet and the air temperature (local temperature) was continuously monitored with maximum minimum thermometers positioned $5 \mathrm{~cm}$ above the trays. The daily temperature data were also obtained from the Meteorological Station of Rio Claro-CEAPLA, located approximately $500 \mathrm{~m}$ from Test 2 site.

Expected germination time courses were obtained from the equation $\mathrm{t}_{\mathrm{G}}=(\mathrm{T}-\mathrm{Tb}) / \theta_{\mathrm{G}}$, where: $\mathrm{t}_{\mathrm{G}}$ is the expected time (in days) to primary root emergence of percentage $\mathrm{G}$; $\mathrm{T}$ is the average daily temperature estimated from the arithmetic mean of the maximum and minimum daily temperatures recorded both from local (Test site) and CEAPLA; Tb is the base temperature (estimated from Test 1) and; $\theta_{\mathrm{G}}$ is the thermal time (in degree-days) required to germination of percentage $\mathrm{G}$, also estimated from Test 1 .

\subsection{Statistical analysis}

A completely randomized experimental design was used for all experiments, with a $5 \%$ significance level $(\alpha=0.05)$ being adopted for the statistical analyses. In Test 1 , the variables germinability $(\mathrm{G} \%)$, mean germination rate $(\mathrm{R})$, and germination synchronization (U) were compared through analysis of variance (ANOVA) followed by Tukey test (Santana and Ranal, 2004). The degree-days model parameters $\left(\mathrm{Tb}, \mathrm{Tc}\right.$ and $\left.\theta_{\mathrm{T}}\right)$ were estimated from linear regressions of the germination rate (reciprocal of time to germination of a given percentage) on temperature, as well as by probit regressions as described above. In Test 2 , the observed and expected germination time courses were compared using chi-square test (Santana and Ranal, 2004).

\section{Results}

According to Test 1 , the seed batch showed a maximum germinabilty of $70.5 \%$ at $18.5{ }^{\circ} \mathrm{C}$, and the temperature interval within which maximum $\mathrm{G} \%$, R and synchronization (lower U) values intercept was from $31.5^{\circ} \mathrm{C}$ to $34.5^{\circ} \mathrm{C}$, which was then regarded as optimum for the seed batch (Figure 1). In the infra optimum temperature range (between $8^{\circ} \mathrm{C}$ and $31.5^{\circ} \mathrm{C}$ ) both germinability and germination rate increased with temperature, whereas at temperatures upper than $34.5^{\circ} \mathrm{C}$ the germination decreased with $\mathrm{T}$ (Figure 1).

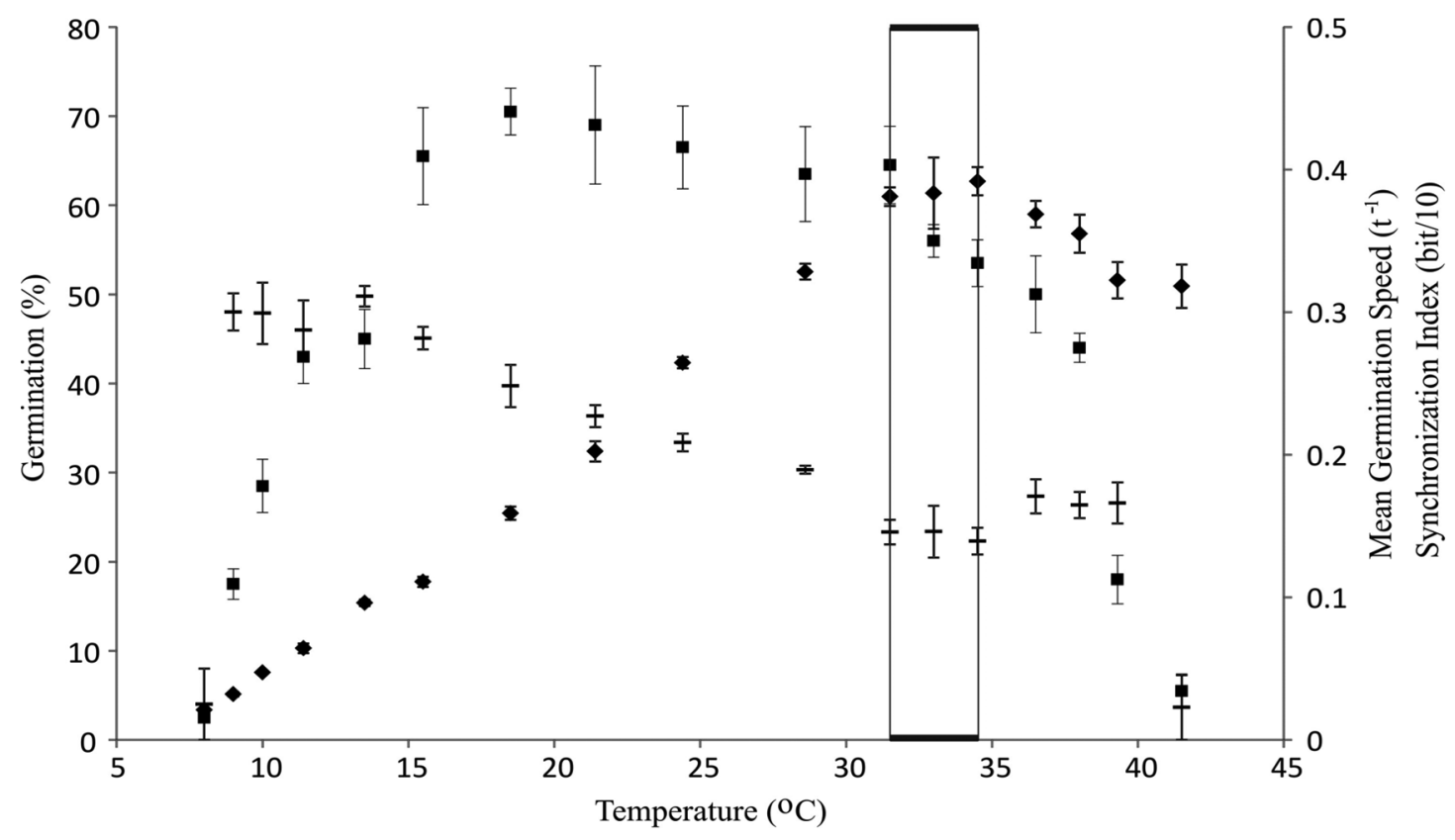

Figure 1. Temperature dependence on the percentage $(\boldsymbol{\bullet})$, germination rate $(\downarrow)$ and synchronization $(\boldsymbol{C})$ of braquiarão seeds at constant temperatures. Vertical bars represent the standard error of the mean, while the area inscribed by the vertical rectangle indicates the thermal range in which the highest percentages, rates and synchronization occur concurrently. 
Ungerminated seeds remaining after completion of the germination assay were dead, according to tetrazolium testing. At temperatures below $15.5^{\circ} \mathrm{C}$ and above $38^{\circ} \mathrm{C}$ the germinabilities were lower than $50 \%$, precluding the germination rate determination for percentage fractions above $50 \%$.

The temperature dependence on the germination rate $\left(1 / t_{G}\right)$ for different seed fractions could be described by linear models both at infra optimum $\left(8^{\circ} \mathrm{C}\right.$ to $\left.21.4{ }^{\circ} \mathrm{C}\right)$ and supra optimum (above $33{ }^{\circ} \mathrm{C}$ ) temperatures (Figure 2). One can observe relatively little variation in $\mathrm{Tb}$ (see intercepts on abscissa) among the fractions at temperatures below the optimum, while above the optimum different fractions tend to have different maxima $\left(\mathrm{Tc}_{(\mathrm{G})}\right)$ (Figure 2). Thus we assume that $\mathrm{Tb}$ did not vary among the seeds and that different seed fractions require different $\theta_{(\mathrm{G})}$ (reciprocal of the slope of the regression line) to germinate at infra optimum temperatures, and that $\theta$ is equal and $\mathrm{Tc}_{(\mathrm{G})}$ varies among individual seeds at supra optimum $\mathrm{T}$. The assumptions that $\theta_{(\mathrm{G})}$ and $\mathrm{Tc}_{(\mathrm{G})}$ are normally distributed among seeds enable the use of probit regression method for estimating the distribution of the parameters $\theta_{(50)}$, $\sigma_{\theta(\mathrm{G})}, \mathrm{Tb}, \theta, \mathrm{Tc}_{(50)}$ and $\sigma_{\mathrm{Tc}(\mathrm{G})}$, which values are displayed at Table 1 . The values for base $\left(\mathrm{Tb}=7.4{ }^{\circ} \mathrm{C}\right)$ and median ceiling temperatures $\left(\mathrm{Tc}_{(50)}=38.0^{\circ} \mathrm{C}\right)$ were close to the respective values $\left(8^{\circ} \mathrm{C}\right.$ and $\left.36.5^{\circ} \mathrm{C}\right)$ obtained through the mean germination rate method (see above). In general, the curves generated from the model parameters described

Table 1. Thermal parameters of the isothermal germination of Urochloa brizantha at infra optimal $\left(8-21.4{ }^{\circ} \mathrm{C}\right)$ and supra optimal $\left(33-41.5{ }^{\circ} \mathrm{C}\right)$ temperatures, determined by probit analysis: base temperature $(\mathrm{Tb})$; median thermal time $\left(\theta_{(50)}\right)$; standard deviation of thermal time $\left(\sigma_{\theta(\mathrm{G})}\right)$; thermal time constant for supra optimum temperatures $(\theta)$; median $\mathrm{Tc}\left(\mathrm{Tc}_{(50)}\right)$ and standard deviation of $\mathrm{Tc}\left(\sigma_{\mathrm{TcG})}\right)$.

\begin{tabular}{ccccccc}
\hline $\begin{array}{c}\text { interval } \\
\left({ }^{\circ} \mathbf{C}\right)\end{array}$ & $\begin{array}{c}\mathbf{T b} \\
\left({ }^{\circ} \mathbf{C}\right)\end{array}$ & $\begin{array}{c}\boldsymbol{\theta}_{(50)} \\
\left({ }^{\circ} \mathbf{C . d}\right)\end{array}$ & $\begin{array}{c}\boldsymbol{\sigma}_{\boldsymbol{\theta ( G )}} \\
\left({ }^{\circ} \mathbf{C . d}\right)\end{array}$ & $\begin{array}{c}\boldsymbol{\theta} \\
\left({ }^{\circ} \mathbf{C ~ d}\right)\end{array}$ & $\begin{array}{c}\mathbf{T c}_{(50)} \\
\left({ }^{\circ} \mathbf{C}\right)\end{array}$ & $\begin{array}{c}\boldsymbol{\sigma}_{\mathrm{Tc}(\mathrm{G})} \\
\left({ }^{\circ} \mathbf{C}\right)\end{array}$ \\
\hline $8-21.4$ & 7.4 & 93.0 & 19.4 & - & - & - \\
$33-41.5$ & - & - & - & 13.2 & 38.0 & 1.9 \\
\hline
\end{tabular}

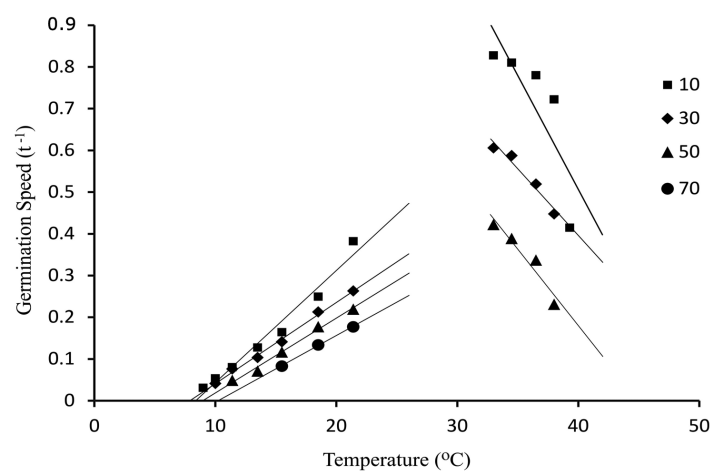

Figure 2. Relationship of germination rate of braquiarão for percentages $10 \%(\boldsymbol{\bullet}), 30 \%(\bullet), 50 \%(\boldsymbol{\Delta})$ and $70 \%(\bullet)$ to temperature, both below and above the optimum $\left(30^{\circ} \mathrm{C}\right)$. with reasonable accuracy the isothermal germination of Urochloa brizantha both at infra (Figure 3A) and supra optimum temperatures (Figure 3B).

In the Test 2, carried out under fluctuating temperature regime, the time courses generated by the model best described the observed germination (symbols in Figure 4) of seeds sown from March to August, with no significant difference $(\alpha=5 \%)$ between the values generated by the model (thermal time either calculated from local or meteorological station temperature recordings) and the observed ones for assays performed in March, May, July and August (Figure 4).

\section{Discussion}

The thermal window within which braquiarão seeds could germinate $\left(8{ }^{\circ} \mathrm{C}\right.$ to $41.5^{\circ} \mathrm{C}$ ) was similar to that observed in several other tropical grasses, such as Pennisetum typhoydes (Garcia-Huidobro et al., 1982), Themeda australis, Chrysopogon fallax, Sorghum plumosum, Chrysopogon latifolius and Sorghums tipoideum (Mott, 1978). Furthermore, early works performed with different batches of Urochloa brizantha seeds (Horibe, not published) showed that minimum and maximum germination temperatures stood around $10.0^{\circ} \mathrm{C}$ and $40.0^{\circ} \mathrm{C}$, respectively, what is very close to the results obtained in this experiment, showing that many tropical grasses require similar temperature ranges to germinate and that cardinal temperatures among different $U$. brizantha populations may be relatively close to each other. The optimum temperature range for germination
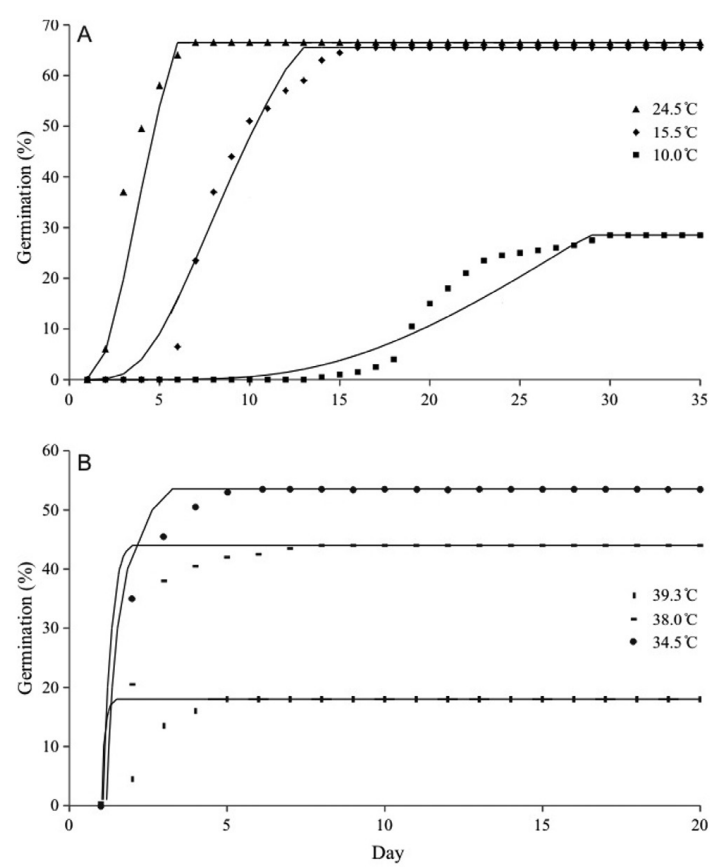

Figure 3. Germination time courses of braquiarão seeds at infra-optimal (A) and supra-optimal (B) temperatures. Symbols are the actual data and the lines represent the expected germination according to the degree-days model. 

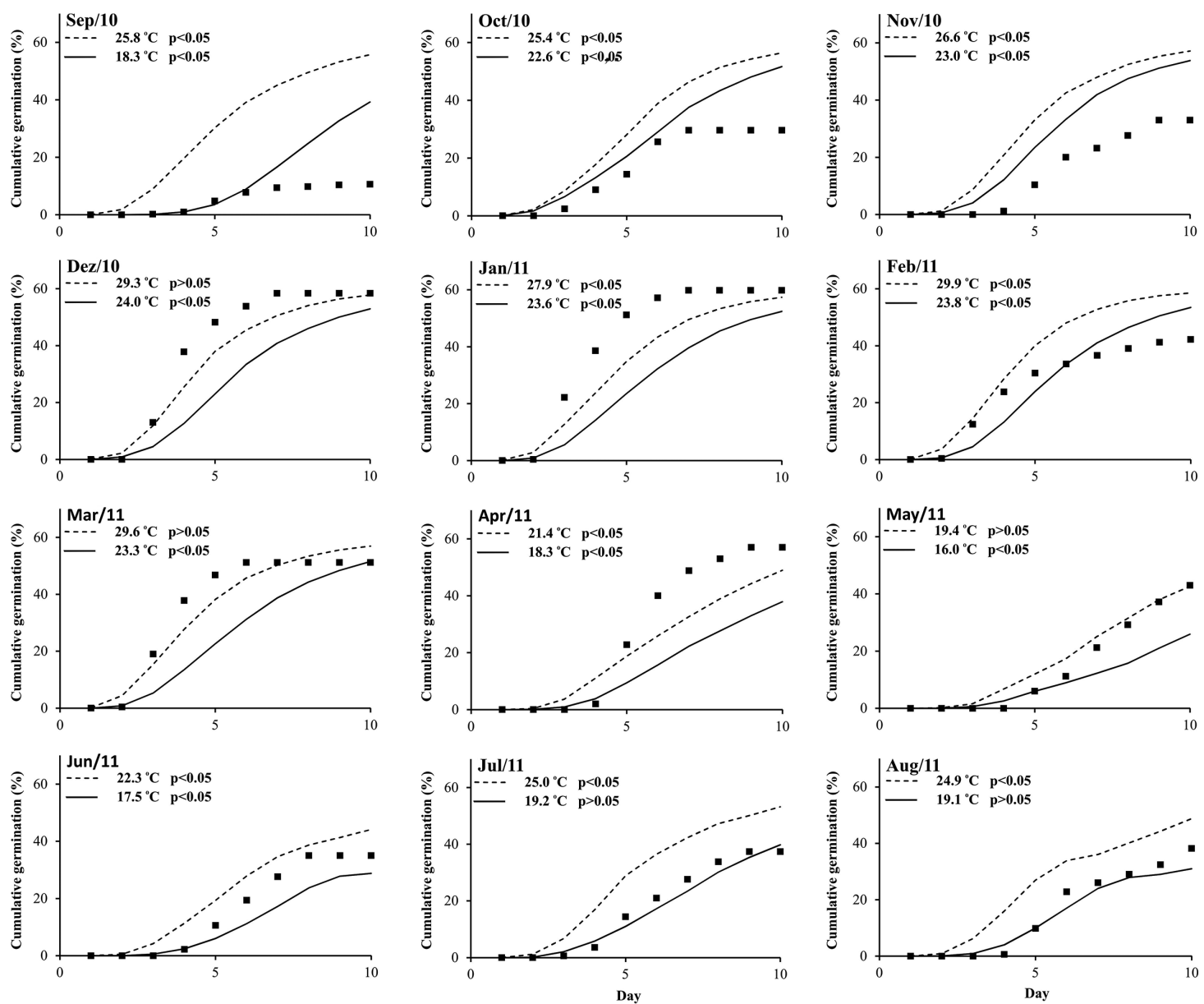

Figure 4. Cumulative monthly germination percentage of braquiarão seeds under uncontrolled temperature, from September 2010 to August 2011. Symbols ( $\mathbf{\square}$ ) are the observed data, and lines represent the expected germination based on thermal time model using the local temperature (continuous line) and the temperature recorded at meteorological station (dashed line). Average temperatures during the experiment are shown in the graph.

found in this work $\left(31.5^{\circ} \mathrm{C}\right.$ to $\left.34.5^{\circ} \mathrm{C}\right)$ is close to the optimum temperature for growth of many tropical grasses such as Brachiaria ruziziensis $\left(28-33^{\circ} \mathrm{C}\right), B$. humidicola $\left(32-35^{\circ} \mathrm{C}\right), B$. dura $\left(30-35^{\circ} \mathrm{C}\right), B$ decumbens $\left(30-35^{\circ} \mathrm{C}\right)$, Pennisetum pedicellatum $\left(30-35^{\circ} \mathrm{C}\right)$ and Urochloa panicoides $\left(25-40{ }^{\circ} \mathrm{C}\right.$ ) (Skerman and Riveros, 1990), as well as for germination and emergence of 11 forage grasses $\left(29-37^{\circ} \mathrm{C}\right)$ (Puga et al., 2011). The thermal interval is also similar to the optimum growth temperature reported for the species (30-35 ${ }^{\circ} \mathrm{C}$ ) (Skerman and Riveros, 1990), suggesting a relationship between germination and growth rate in terms of response to temperature by $U$. brizantha. In agreement with that assumption, Silva et al. (2012) found a Tb of $10.5^{\circ} \mathrm{C}$ for shoot dry matter production by $U$. brizantha grown in field plots, what is relatively close to $\mathrm{Tb}$ values (around $9^{\circ} \mathrm{C}$ ) estimated in this work from the relationship between germination rate and temperature (see below).

The relationships of germination rates for specific germination percentages of Urochloa brizantha seeds to incubation temperature suggest that seeds vary little in terms of base temperature for germination $(\mathrm{Tb})$, which was found to vary from 8 to $10{ }^{\circ} \mathrm{C}$, whereas different seed fractions require different thermal times allowing germination, with a median value (degree days for $50 \%$ of the seeds to germinate) of $\cong 56{ }^{\circ} \mathrm{C}$ day. The $\mathrm{Tb}$ value obtained here is higher than that $\left(6^{\circ} \mathrm{C}\right)$ found by Ustarroz (2011) with Urochloa panicoides collected in Cordoba (Argentina), while the median thermal time for a non-dormant batch from that species was found to be similar $\left(55^{\circ} \mathrm{C}\right.$ day $)$ to $U$. brizantha. Otherwise, above the optimum, where the germination rate decreases with $\mathrm{T}$, the ceiling temperatures (Tc) seems to vary among individual seeds of $U$. brizantha, which exhibited a median $\mathrm{Tc}$ of $\cong 45^{\circ} \mathrm{C}$, which correspond to the maximum temperature recorded for $U$. panicoides (Ustarroz, 2011). Although more populations must be tested in order to discuss a possible correlation between temperature dependence on germination and geographical distribution of Urochloa, the results from comparisons between the $U$. brizantha seeds matured under warmer conditions and the more southern $U$. panicoides seed 
collection, suggest that any difference in response to temperature between species can be accounted for by changes in $\mathrm{Tb}$ rather than in thermal time requirements, which are influenced by geographic origin of the species and are usually determined through changes in $\mathrm{Tb}$ (Trudgill et al., 2005). The relationship between germination rate and incubation temperature found for $U$. brizantha presented a similar pattern to other grasses such as Chloris gayana, Brachiaria mutica and Andropogon gayanus, and differed from Lolium perenne, Cynodon dactylon and Pennicetum ciliare (Puga et al., 2011), showing that one cannot take as a rule that $\mathrm{Tc}$ varies with seed while $\mathrm{Tb}$ is relatively constant within population.

When the probit transformed percentages from germination time courses at different temperatures were combined into a common regression in order to assess for base temperature and other thermal parameters, the obtained values for $\mathrm{Tb}\left(7.4^{\circ} \mathrm{C}\right), \theta_{(50)}\left(93^{\circ} \mathrm{Cd}\right), \theta\left(13.2^{\circ} \mathrm{Cd}\right)$ and $\mathrm{Tc}_{(50)}\left(38^{\circ} \mathrm{C}\right)$ differed from that obtained through the regressions of the germination rate $(\mathrm{R})$ on incubation temperature. Otherwise, the $\mathrm{Tb}$ and $\mathrm{Tc}_{(50)}$ values obtained from probit analysis were close to the values $\left(8^{\circ} \mathrm{C}\right.$ and $36.5^{\circ} \mathrm{C}$, respectively) found by extrapolation of the regression line of the average germination rate (Labouriau and Agudo, 1987) on temperature. The discrepancy between the probit analysis and the estimations from regression of $\mathrm{R}$ on temperature may be due to the variation in thermal time does not closely approximate a normal distribution and/or to some variation in Tb within population (Bradford, 1995), in general, however, the curves generated from the model parameters described with reasonable accuracy the isothermal germination of Urochloa brizantha, suggesting that main model assumptions were met. Otherwise, one can not preclude a concomitant variation of $\mathrm{Tc}_{(\mathrm{G})}$ and $\theta_{\mathrm{G}}$ (Bradford, 1995) within U. brizantha population, although that would be difficult to confirm for all percentage fractions, considering the sudden drop in germinability under temperatures approaching Tc. The effect of supra optimum temperatures can explain in part how efficient is the model in describing the germination time courses of $U$. brizantha seeds at fluctuating temperatures, with the thermal time model best describing the observed germination between March and August in which the median temperatures were lower than in the September to February period. The use of average temperatures (arithmetic mean between the minimum and maximum temperatures) would disconsider the effect of temperature peaks in the warmest hours of the day, which could affect negatively the germination of $U$. brizantha. According to Forcella et al. (2000), exposure to extremely high or low temperatures during germination can cause physiological changes in seeds and, consequently, alter the parameters of the degree-days model, making it less accurate.

It was observed that, even under a daily irrigation regime, Urochloa brizantha germinability under uncontrolled temperatures tends to be lower from May to October as compared to the period December-April. Considering that the thermal time model accuracy in predicting emergence of a grass (Echinochloa phyllopogon) can be reduced under moderate moisture stress (Boddy et al., 2012), one cannot discard that $U$. brizantha seeds may have been exposed to a moderate stress caused by an excess of water evaporation from the soil due to warmer temperatures in the greenhouse. Otherwise, these data also suggest seasonality in the germination response of braquiarão seeds, which could be associated with secondary dormancy mechanisms (Bradford, 2002; Bewley et al., 2013). Some studies have shown that models based on degree-days are less effective in describing the germination in seeds that present any kind of dormancy, which would be associated with variations in parameters such as $\mathrm{Tb}$ and $\mathrm{Tc}$ (Bradford, 1995; Finch-Savage and Leubner-Metzger, 2006). In this study, we used a seed batch with low or virtually no dormancy, however it is possible that, depending on the environmental conditions, grass seeds can develop secondary dormancy (Harris, 1961; Honek and Martinková, 1992). Furthermore, Urochloa brizantha has their genetic base only marginally improved since its introduction in Brazil, persisting as a wild species in the field, very sensitive to environmental conditions and with irregular germination (Pitelli and Pavani, 2005), therefore difficult to model.

The thermal time model produced germination parameters which described well the germination of Urochloa brizantha under isothermal conditions, however the model failed to predict germination when the seeds were submitted to wide range of thermal fluctuations, what may be related to the physiological status of the seeds, thus affecting how the seed perceives its thermal environment through the parameters $\mathrm{Tc}$ (ceiling temperature), $\mathrm{Tb}$ (base temperature) and $\theta_{\mathrm{G}}$ (thermal time).

\section{Acknowledgements}

The authors thank Coordenação de Aperfeiçoamento de Pessoal de Nível Superior-CAPES, for the master grant awarded to EAN.

\section{References}

BARBOSA, E.G., PIVELLO, V.R. and MEIRELLES, S.T., 2008. Allelopathic evidence in Brachiariadecumbens and its potential to invade the Brazilian Cerrados. Brazilian Archives of Biology and Technology, vol. 51, no. 4, pp. 825-831. http://dx.doi.org/10.1590/ S1516-89132008000400021.

BEGON, M., TOWNSEND, C.R. and HARPER, J.L., 2007. Ecologia de individuos a ecossistemas. Porto Alegre: Artmed.

BELO, R.G., TOGNETTI, J., BENECH-ARNOLD, R. and IZQUIERDO, N.G., 2014. Germination responses to temperature and water potential as affected by seed oil composition in sunflower. Industrial Crops and Products, vol. 62, pp. 537-544. http://dx.doi. org/10.1016/j.indcrop.2014.09.029.

BEWLEY, J.D., BRADFORD, K., HILHORST, H.W.M. and NONOGAKI, H., 2013. Seeds: physiology of development, germination and dormancy. New York: Springer.

BODDY, L.G., BRADFORD, K.J. and FISCHER, A.J., 2012. Population-based threshold models describe weed germination 
and emergence patterns across varying temperature, moisture and oxygen conditions. Journal of Applied Ecology, vol. 49, no. 6, pp. 1225-1236. http://dx.doi.org/10.1111/j.1365-2664.2012.02206.x.

BRADFORD, K.J., 1995. Water relations in seed germination. In: J. KIGEL and G. GALILI, eds. Seed development and germination. New York: Marcel Dekker, pp. 351-396.

BRADFORD, K.J., 2002. Applications of hydrothermal time to quantifying and modeling seed germination and dormancy. Weed Science, vol. 50, no. 2, pp. 248-260. http://dx.doi.org/10.1614/00431745(2002)050[0248:AOHTTQ]2.0.CO;2.

BRASIL. Ministério da Agricultura, Pecuária e Abastecimento, 2009. Regras para análise de sementes. Brasília. 398 p.

CARDOSO, V.J.M., 2010. An adapted thermal-gradient block for the germination of photoblastic seeds. Brazilian Archives of Biology and Technology, vol. 53, no. 6, pp. 1267-1277. http:// dx.doi.org/10.1590/S1516-89132010000600002.

CARDOSO, V.J.M., 2011. Metodologia para análise da dependência térmica da germinação pelo modelo de graus.dia. Oecologia Australis, vol. 15, no. 2, pp. 236-248. http://dx.doi.org/10.4257/ oeco.2011.1502.04.

FINCH-SAVAGE, W. and LEUBNER-METZGER, G., 2006. Seed dormancy and the control of germination. The New Phytologist, vol. 171 , no. 3, pp. 501-523. http://dx.doi.org/10.1111/j.14698137.2006.01787.x. PMid:16866955.

FORCELLA, F., BENECH ARNOLD, R.L., SANCHEZ, R. and GHERSA, C.M., 2000. Modelling seedling emergence. Field Crops Research, vol. 67, no. 2, pp. 123-139. http://dx.doi.org/10.1016/ S0378-4290(00)00088-5.

GARCIA-HUIDOBRO, J., MONTEITH, J.L. and SQUIRE, G.R., 1982. Time, temperature and germination of pearl millet (Pennisetumtyphoides). I. Constant temperature. Journal of Experimental Botany, vol. 33, pp. 288-296. http://dx.doi. org $/ 10.1093 / \mathrm{jxb} / 33.2 .288$.

HARRIS, G.S., 1961. The periodicity of germination in some grass species. New Zealand Journal of Agricultural Research, vol. 4 , no. 3-4, pp. 253-260. http://dx.doi.org/10.1080/002882 33.1961.10420371.

HONEK, A. and MARTINKOVÁ, Z., 1992. The induction of secondary seed dormancy by oxygen deficiency in a barnyard grass Echinoloa crus-galli. Experientia, vol. 48, no. 9, pp. 904906. http://dx.doi.org/10.1007/BF02118432.
LABOURIAU, L.G. and AGUDO, M., 1987. On the physiology of seed germination in Salvia hispanica L. I. Temperature effects. Anais da Academia Brasileira de Ciências, vol. 59, pp. 37-56.

MOTT, J.J., 1978. Dormancy and germination in five native grass species from Savannah Woodland communities of the Northern Territory. Australian Journal of Botany, vol. 26, no. 5, pp. 621631. http://dx.doi.org/10.1071/BT9780621.

NORI, H., MOOT, D.J. and BLACK, A.D., 2014. Thermal time requirements for germination of four annual clover species. New Zealand Journal of Agricultural Research, vol. 57, no. 1, pp. 3037. http://dx.doi.org/10.1080/00288233.2013.863786.

PANCERA JUNIOR, E.J., 2011. Produção de sementes do capim-braquiária submetido à irrigação e doses de nitrogênio. Maringá: Universidade Estadual de Maringá. Masters Dissertation.

PITELLI, R.A. and PAVANI, M.C.M.D., 2005. Feralidade vegetal e transgeníase: evolução adaptativa das plantas invasoras. Biotecnologia Ciência \& Desenvolvimento, vol. 34, pp. 100-104.

PUGA, N.D., CORRAL, J.A.R., EGUIARTE, D.R.G., HERNÁNDEZ, G.N., RAMÍREZ, F.J.P. and RODRÍGUEZ, S.H.C., 2011. Development cardinal temperatures of the plantingemergence stage for 11 forage grasses. Revista Mexicana de Ciências Pecuárias, vol. 2, pp. 347-357.

SANTANA, D.G. and RANAL, M.A., 2004. Análise da germinação: um enfoque estatístico. Brasília: Editora UNB.

SILVA, E.A., SILVA, W.J., BARRETO, A.C., OLIVEIRA JUNIOR, A.B., PAES, J.M.V., RUAS, J.R.M. and QUEIROZ, D.S., 2012. Dry matter yield, thermal sum and base temperatures in irrigated tropical forage plants. Revista Brasileira de Zootecnia, vol. 41, no. 3, pp. 574-582. http://dx.doi.org/10.1590/S151635982012000300014 .

SKERMAN, P.J. and RIVEROS, F., 1990. Tropical grasses. Roma: FAO. $832 \mathrm{p}$.

TRUDGILL, D.L., HONEK, A., LI, D. and VAN STRAAALEN, N.M., 2005. Thermal time: concepts and utility. Annals of Applied Biology, vol. 146, no. 1, pp. 1-14. http://dx.doi.org/10.1111/j.17447348.2005.04088.x.

USTARROZ, D., 2011. Bioecologia de Urochloa panicoides. Buenos Aires: Faculdad de Agronomia, Universidad de Buenos Aires. PhD Thesis. 